\title{
Prestasi Akademik Siswa Sekolah Menengah Pertama (SMP) Ditinjai Dari Konsep Diri Akademik dan Kecerdasan Emosi
}

\author{
Anwar Fuadi \\ Universitas Islam Negeri Antasari Banjarmasin \\ Email : anwarfuadi@uin-antasari.ac.id
}

\begin{abstract}
This study aims to determine the correlation between junior high school (SMP) student academic achievement in terms of academic self-concept and emotional intelligence. The hypothesis of this study is that there is a positive correlation between academic self-concept and emotional intelligence with the academic achievement of junior high school students. Subjects in this study amounted to 193 class students, data collection was carried out using two scales, the academic self-concept scale and emotional intelligence scale and for academic achievement in the form of documentation of students' final semester scores. Data analysis using multiple regression analysis techniques. The results showed that there is: a very significant relationship between academic self-concept and emotional intelligence with academic achievement.
\end{abstract}

KEYWORDS : academic self-concept, emotional intelligence, and academic achievement

\section{ABSTAK}

Penelitian ini bertujuan untuk mengetahui korelasi prestasi akademik siswa sekolah menengah pertama (SMP) yang ditinjau dari konsep diri akademik dan kecerdasan emosi. Hipotesis penelitian ini adalah ada korelasi positif antara konsep diri akademik dan kecerdasan emosi dengan prestasi akademik siswa SMP. Subjek pada penelitian ini berjumlah 193 orang siswa kelas, pengumpulan data dilakukan dengan menggunakan dua skala yaitu skala konsep diri akademik dan skala kecerdasan emosi serta untuk prestasi akademik berupa dokumentasi nilai akhir semester siswa. Analisis data menggunakan teknik analisis regresiganda. Hasil penelitian menunjukkan bahwa ada: hubungan yang sangat signifikan antara konsep diri akademik dan kecerdasan emosi dengan prestasi akademik.

KATA KUNCI konsep diri akademik, kecerdasan emosi, dan prestasi akademik

\section{Pendahuluan}

Pendidikan merupakan salah satu aspek penting pembangunan bangsa. Perkembangan suatu negara diukur dari pesatnya perkembangan pendidikan yang berkualitas dan diakui oleh dunia. Prestasi akademik merupakan salah satu tolok ukur kemajuan pendidikan yaitu dengan melihat pada hasil belajar yang dicapai oleh siswa. Belajar merupakan proses diri menuju kedewasaan. Prestasi akademik adalah prestasi belajar berbentuk angka sebagai deskripsi tingkat penguasaan atau penyelesaian tugas- 
tugas belajar anak didik dalam periode tertentu (Nurhasanah \& Satrio Adi, 2018). Prestasi belajar diukur dari berbagai aspek, menurut (Azwar, 2013) pengukuran prestasi dilihat berdasarkan aspek-aspek yang dimiliki seseorang dalam kompetensinya sebagai seorang pelajar meliputi aspek kognitif, afektif dan psikomotorik. Suryabrata (2015) menyebutkan ada 3 dasar yang melandasi pentingnya melakukan pengukuran atau penilaian terhadap keberhasilan pendidikan. Pertama, Aspek psikologis (Internal), aspek didaktis (guru) dan aspek administratif, (pengukuran)

Rendahnya prestasi akademik siswa disebabkan oleh banyak faktor (Suryabrata, 2015). Dua faktor dominan yang mempengaruhi prestasi siswa yaitu faktor internal dan faktor eksternal (Suryabrata, 2015). Faktor internal siswa terdiri dari faktor fisiologis dan psikologis, sedangkan faktor yang mempengaruhi secara eksternal adalah lingkungan seperti guru dan sekolah. Faktor internal yang mempengaruhi prestasi belajar secara psikologis individu antara lain motivasi, inteligensi, resiliensi, konsep diri akademik, dan kecerdasan emosi (Slameto, 2017).

Dari data evaluasi akhir semester sekolah SMP "I" tahun ajaran 2018/2019, disebutkan hampir 37 \% siswa SMP "I" yang bersikap kurang berani untuk tampil di depan kelas disebabkan karena rendahnya rasa percaya diri siswa terhadap kemampuan dan potensi diri. Sikap lainnya yang terlihat pada siswa adalah perilaku mencontek pada saat ulangan (28\%). Perilaku mencontek disebabkan karena ketidak-siapan belajar siswa dan juga disebabkan karena siswa kurang percaya diri dengan kemampuan yang dimilikinya. Di sisi lain ketika berada di dalam kelas ada siswa yang berbuat "nakal" dengan mengganggu temannya yang lain ketika sedang belajar dan selalu membantah guru jika dinasehati (31\%), hal ini menimbulkan kegaduhan di dalam kelas dan otomatis menjadikan proses belajar pada jam pelajaran tersebut terganggu.

\section{Kajian Pustaka}

Sikap kurang percaya diri siswa terhadap kemampuan dan potensi dirinya mengindikasikan bahwa adanya konsep diri akademik yang rendah pada diri siswa. Indikator rendahnya konsep diri akademik berdasarkan pendapat (Marsh, 1990) yang menyebutkan faktor yang mempengaruhi rendahnya konsep diri akademik seseorang karena rendahnya kepercayaan diri, penerimaan diri dan penghargaan terhadap diri sendiri. Prestasi yang dicapai seorang individu mempunyai hubungan erat dengan keyakinan akan kemampuan dan rasa keberhasilan yang dimilikinya (Schunk, 2012). Keyakinan 
akan kemampuan diri menunjukkan bahwa siswa memiliki konsep diri akademik yang bagus dan memiliki keinginan untuk berprestasi lebih tinggi. Siswa berprestasi tinggi dan mempunyai konsep diri akademik yang bagus biasanya memiliki rasa ingin tahu lebih banyak terhadap pelajaran di kelas dan aktif di kelas, suka membaca literatur dan sering berdiskusi dengan guru (Michael J r., 2017).

Dari hasil wawancara dan observasi juga diketahui bahwa siswa sering berperilaku mengganggu teman sekelas dan berani membantah guru ketika diingatkan, hal ini mengindikasikan bahwa siswa masih kurang bisa mengelola dan mengontrol emosinya. Individu yang kurang mampu mengendalikan dan mengontrol emosi yang meluap dalam dirinya menunjukkan bahwa individu tersebut memiliki kecerdasan emosi yang kurang. Indikator rendahnya kecerdasan emosi individu, menurut Goleman (2014) salah satunya adalah ketidak mampuan individu dalam mengontrol emosi yang timbul dapat menyebabkan berkurangnya konsentrasi dalam belajar dan merusak hubungan pergaulan antara individu dan lingkungan sosialnya. Individu yang mempunyai kecerdasan emosional yang baik, akan lebih cerdas, penuh pengertian, mudah menerima perasaan-perasaan dan lebih banyak pengalaman dalam memecahkan permasalahannya sendiri, sehingga dalam berhubungan dengan lingkungan sosial mempunyai self-control yang baik ketika akan melakukan tindakan yang dapat merusak (Za'im, 2016).

Woolfolk (2016) menyebutkan bahwa kecerdasan emosi penting bagi perkembangan akademik maupun pekembangan pribadi, seseorang yang memiliki kecerdasan emosi akan mampu mengontrol dan mengelola emosi yang timbul sehingga tidak menghambat proses belajar dirinya dan berperilaku yang merugikan orang lain. Penelitian tentang kecerdasan emosi dan pengaruhnya terhadap prestasi sudah banyak dilakukan, misalnya penelitian oleh (Kashani et al., 2012), menyebutkan bahwa kecerdasan emosi mempunyai hubungan yang positif dengan prestasi akademik siswa. Penelitian ini juga secara bersama- sama meneliti tentang keterlibatan orang tua terhadap prestasi. Hasil penelitian ini diperkuat dengan hasil penelitian yang dilakukan oleh (Billings et al., 2014) menyebutkan bahwa kecerdasan emosi secara meyakinkan dapat mempengaruhi dan meningkatkan prestasi skolastik siswa remaja, dengan kata lain kecerdasan emosi mempunyai peran dalam meningkatkan performa akademik dari siswa.

Ada dua faktor yang mempengaruhi prestasi akademik siswa, yaitu faktor yang berasal dalam diri (internal) dan faktor yang berasal dari luar diri (eksternal). Menurut Bandura (1989) perkembangan 
individu selain dipengaruhi lingkungan (environment) dan perilaku (behaviora), juga dipengaruhi dari dalam diri individu (personality). Walaupun demikian Bandura (1989) menjelaskan bahwa faktor dalam diri individu (personality) memegang peranan penting dalam proses belajar. Prestasi merupakan produk interaksi antara faktor- faktor yang terdapat dalam internal siswa dengan pengaruh-pengaruh yang ada di lingkungannya (Bandura, 1989).

Hasil penelitian terdahulu menyebutkan bahwa selain IQ, Sikap, dan bakat, ada faktor lain yang ikut mempengaruhi prestasi akademik yaitu kecerdasan emosi (Mendoza \& Hontiveros, 2017) dan konsep diri akademik (Costa \& Faria, 2015); (Mega et al., 2014); (Burkhalter, 2014); (Khalaila, 2015); (Marsh \& Martin, 2011). Jadi bisa dikatakan bahwa faktor kecerdasan emosi dan konsep diri akademik juga memegang peranan penting dalam memberikan pengaruh terhadap prestasi akademik.

Preckel et al., (2010); Mclnerney et al., (2012) mendefinisikan konsep diri akademik sebagai persepsi individu terhadap dirinya di bidang akademik. (Marsh et al., 2018) menyebutkan bahwa konsep diri akademik sebagai pendangan, penilaian dan keyakinan individu terhadap kemampuan dirinya di bidang akademik. Terdapat kesamaan pandangan tentang pengertian konsep diri akademik yang dikemukakan oleh para ahli di atas, bahwa konsep diri akademik adalah persepsi siswa terhadap kompetensi dirinya dalam bidang akademik di sekolah ((Skaalvik \& Skaalvik, 2014); (Marsh et al., 2018); (Preckel et al., 2010); (Preckel et al., 2013); (Erten \& Burden, 2014)). Siswa mempersepsi kemampuan dirinya secara total dengan melibatkan berbagai aspek seperti kognitif dan emosi menjadi sikap atau perilaku yang tercemin dalam dirinya ((Skaalvik \& Skaalvik, 2014); (Marsh \& Martin, 2011)).

Marsh et al., (2018) menyebutkan bahwa ada 3 aspek yang mempengaruhi konsep diri akademik, yaitu kepercayaan diri, penerimaan diri dan penghargaan diri. Peneliti menggunakan aspek-aspek konsep diri akademik yang dikemukakan oleh Marsh et al., (2018) yaitu, kepercayaan diri, penerimaan diri dan penghargaan diri.

Kecerdasan emosi merupakan sebuah konsep yang relatif baru dalam dunia psikologi. Kecerdasan emosi merujuk pada mengidentifikasi, memahami dan menerapkan perasaan pribadi dan orang lain (Bornstein, 2018). Goleman (2014) orang yang pertama sekali mempopulerkan istilah emotional intelligence membagi aspek-aspek kecerdasan emosi kepada lima aspek yaitu mengenali emosi diri, mengelola emosi, motivasi, empati, dan keterampilan sosial.

Peneliti menggunakan aspek-aspek kecerdasan emosi yang dikemukakan oleh Goleman (2014) 
yaitu mengenali emosi diri, mengelola emosi, motivasi, empati, dan keterampilan sosial untuk menyusun skala kecerdasan emosi dalam penelitian ini. Hal ini karena menurut peneliti bahwa aspekaspek yang dikemukakan oleh Goleman (2014) sudah mencakup keseluruhan penjelasan secara detail mengenai kecerdasan emosi dan pengungkapan melalui aspek-aspek tersebut lebih mudah dipahami untuk penyusunan skala kecerdasan emosi.

\section{Metode Penelitian}

Penelitian ini dilakukan di sekolah SMP “l” di kabupaten Situbondo, Propinsi Jawa Timur. Kriteria subjek adalah siswa kelas VIII SMP "I" Sukorejo, Kab. Situbondo, Prop. Jawa Timur yang masih aktif. Alasan pemilihan siswa kelas VIII SMP dikarenakan kondisi siswa di sekolah tersebut, jika memilih siswa kelas VII dikhawatirkan mereka belum begitu mengenal kondisi dan situasi sekolah sedangkan siswa kelas IX dikhawatirkan mengganggu persiapan mereka dalam menghadapi UN. Pemilihan siswa kelas VIII peneliti anggap tepat karena mereka sudah mengenal kondisi dan lingkungan sekolah dan sedang tidak menghadapi Ujian Nasional. Sampel di ambil berdasarkan kriteria subjek yang telah ditentukan di atas, dari 364 orang jumlah siswa kelas VIII, peneliti mendapatkan 193 orang siswa yang tersebar di 6 kelas. Penentuan sampel dilakukan dengan cara non-random dengan asumsi bahwa subyek yang dijadikan sampel dalam penelitian ini ditentukan oleh pemegang kebijakan dengan pertimbangan kelas yang pada saat dilakukan pengambilan data tidak ada kegiatan belajar mengajar.

Pengumpulan data dilakukan dengan menggunakan skala. Skala digunakan untuk meneliti variabel konsep diri akademik (27 aitem) dan kecerdasan emosi (28 aitem). Model skala yang digunakan dalam penelitian ini menggunakan model skala Likert, dimana penilaian dalam skala ini meminta kepada responden untuk memberikan jawaban terhadap pernyataan yang sesuai dengan taraf kesesuaian yang diingini responden. Bentuk jawaban terbagi kepada 5 pilihan, yaitu, sangat sesuai (SS), sesuai (S), netral (N), tidak sesuai (TS), dan sangat tidak sesuai (STS).

Selain menggunakan skala, dalam penelitian ini juga menggunakan dokumentasi untuk memperoleh data jumlah ujian akhir semester sekolah pada empat mata pelajaran kelas VIII, yaitu Bahasa Indonesia, Bahasa Inggris, IPA, dan Matematika. Penjumlahan nilai akhir ke-empat mata pelajaran itu kemudian dibagi 4 menghasilkan rerata nilai. Rerata nilai akhir keempat mata pelajaran itu akan digunakan sebagai indikator prestasi akademik. Teknik analisis data yang digunakan dalam 
pengujian hipotesis penelitian ini akan menggunakan teknik analisis regresi ganda.

\section{Hasil Penelitian}

Analisis deskriptif data penelitian dilakukan untuk memperoleh informasi secara umum mengenai keadaan distribusi skor yang diperoleh subjek penelitian pada tiap variabel penelitian. Berdasarkan data sampel dan perhitungan analisis data diperoleh gambaran deskripsi statistik dari masing-masing variabel penelitian sebagai berikut:

Tabel 1 : Deskripsi Data Variabel Penelitian

\begin{tabular}{|c|c|c|c|c|c|c|c|c|}
\hline \multirow{2}{*}{ Variabel } & \multicolumn{3}{|c|}{ Data Hipotetik } & \multicolumn{5}{|c|}{ Data Empirik } \\
\hline & Min & Max & Mean & SD & Min & Max & Mean & SD \\
\hline $\begin{array}{l}\text { Konsep diri } \\
\text { akademik }\end{array}$ & 27 & 135 & 81 & 18 & 59,00 & 128 & 97,2124 & 14,12155 \\
\hline $\begin{array}{l}\text { Kecerdasan } \\
\text { emosi }\end{array}$ & 28 & 140 & 84 & 18,6667 & 68,00 & 132 & 102,1244 & 11,05173 \\
\hline Prestasi & 0 & 100 & 50 & 16,67 & 50,25 & 75 & 66,4759 & 4,31844 \\
\hline
\end{tabular}

Berdasarkan Tabel 1 di atas dapat dilihat perbandingan nilai hipotetik dan nilai empiris pada masing-masing variabel penelitian. Pada variabel konsep diri akademik dapat dilihat bahwa mean hipotetik sebesar 81 lebih rendah dibandingkan dengan mean empiris yaitu sebesar 97,2124. Data ini menunjukkan bahwa konsep diri akademik dari sampel penelitian lebih tinggi daripada konsep diri akademik populasi padaumumnya.

Hasil perbandingan nilai hipotetik dan nilai empiris pada variabel kecerdasan emosi juga menunjukkan bahwa kecerdasan emosi sampel penelitian lebih tinggi daripada kecerdasan emosi populasi pada umumnya. Nilai hipotetik kecerdasan emosi sebesar 84 sedangkan nilai empirisnya sebesar 102,1244.

Hasil perbandingan nilai hipotetik dan nilai empiris variabel prestasi akademik menunjukkan bahwa nilai hipotetik prestasi akademik sebesar 50 lebih kecil dibandingkan dengan nilai empiris prestasi akademik yaitu sebesar 66,4759. Data ini menunjukkan bahwa prestasi akademik dari sampel penelitian lebih besar daripada prestasi akademik populasi padaumumnya. 
Uji prasyarat perlu dilakukan sebelum data dianalisis dengan tujuan supaya diketahui apakah data yang dikumpulkan layak untuk dianalisis dengan analisis regresi linier berganda atau tidak. Uji prasyarat meliputi uji normalitas sebaran, uji linieritas, uji multikolinieritas dan uji heteroskedastisitas.

1. Uji Normalitas sebaran

Uji normalitas dilakukan dengan menggunakan teknik Kolmogorv-Smirnov Z (K-SZ) dengan bantuan program SPSS, bertujuan untuk mengetahui apakah data yang digunakan dalam penelitian ini berdistribusi normal atau tidak.

Keseluruhan rangkuman hasil uji normalitas sebaran data variabel dapat dilihat pada tabel berikut ini:

Tabel 2: Hasil Uji Normalitas Sebaran

\begin{tabular}{lccccc}
\multicolumn{1}{c}{ Variabel } & Mean & SD & K-SZ & P & Keterangan \\
\hline Konsep Diri Akademik & 97,6632 & 13,57946 & 0,464 & 0,982 & Normal \\
\hline Kecerdasan Emosi & 102,7409 & 10,41809 & 0,626 & 0,827 & Normal \\
\hline Prestasi Akademik & 66,4759 & 4,31844 & 0,911 & 0,377 & Normal \\
\hline
\end{tabular}

2. Uji Linearitas

Uji linieritas bertujuan untuk mengetahui hubungan antara variabel bebas dan variabel terikat. Kaidah yang digunakan dalam uji linieritas hubungan antara variabel bebas dan variabel terikat ditentukan oleh nilai signifikansi $p$ pada tabel linieritas. Jika $p<0,01$ maka hubungan antara variabel adalah linier dan jika $p>0,05$ maka hubungan tidak linier.

Tabel 3: Rangkuman Hasil Uji Linieritas

\begin{tabular}{lccc}
\multicolumn{1}{c}{ Variabel } & F & $\begin{array}{c}\text { Sig } \\
(\mathbf{p}<\mathbf{0 , 0 1 )})\end{array}$ & Keterangan \\
\hline $\begin{array}{l}\text { Konsep diri akademik dengan prestasi } \\
\text { akademik }\end{array}$ & 40,974 & 0,00 & Linier \\
\hline $\begin{array}{l}\text { Kecerdasan Emosi dengan Prestasi } \\
\text { Akademik }\end{array}$ & 29,154 & 0,00 & Linier \\
\hline
\end{tabular}

3. Uji Multikolinearitas

Uji multikolinearitas bertujuan untuk membuktikan ada tidaknya hubungan yang linier antara variabel bebas (independent variabel) yang satu dengan variabel bebas lainnya (Ghozali, 2016). Model regresi yang baik seharusnya tidak terjadi linieritas di antara variabel independen. 
Untuk mengetahui multikolinearitas variabel dapat dilihat pada Value Inflation Factor(VIF) dan nilai Tolerance, dimana nilai VIF tidak melebihi 10 dan nilai Tolerance tidak kurang dari 0,10 maka bisa dikatakan bahwa tidak terjadi multikolinearitas pada variabel independen penelitian.

Tabel 4 : Hasil Uji Multikolinieritas

\begin{tabular}{cccc} 
Variabel & Tolerance & VIF & Keterangan \\
\hline Konsep diri akademik & & & $\begin{array}{c}\text { Tidak terjadi } \\
\text { multikolinieritas }\end{array}$ \\
\hline Kecerdasan Emosi & 0,860 & 1,163 & \\
\hline
\end{tabular}

4. Uji Heteroskedastisitas

Uji heteroskedastisitas bertujuan untuk menguji apakah dalam model regresi terjadi ketidaksamaan varian dari residual satu pengamatan ke pengamatan yang lain. Jika varian dari residual satu pengamatan ke pengamatan lain tetap, maka disebut Homoskedastisitas dan jika berbeda disebut heteroskedastisitas. Model regresi yang baik adalah yang homoskedastisitas atau tidak terjadi heteroskedastisitas (Ghozali, 2016)

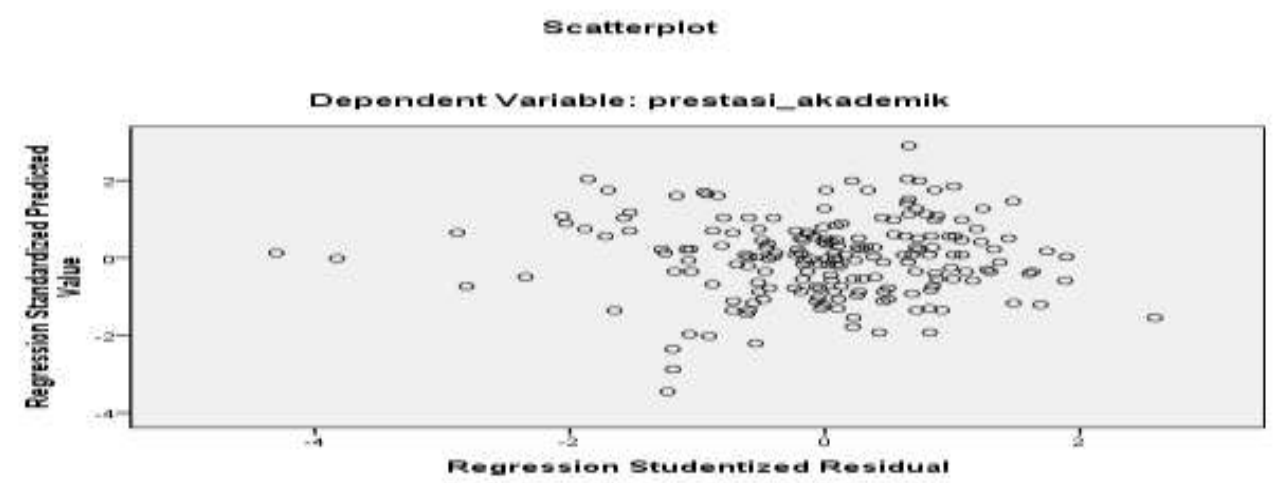

Gambar 1 : Scatterplot Uji Heteroskedastisitas

Setelah keempat uji prasyarat terpenuhi (uji normalitas, uji linieritas, uji multikolinieritas dan uji heteroskedastisitas) terpenuhi, maka uji hipotesis menggunakan analisis regresi dapat dilakukan.

\section{Uji Hipotesis}

Pengujian hipotesis dalam penelitian ini menggunakan analisis regresi ganda dengan bantuan program SPSS 17.0 
Tabel 5: Hasil Uji Regresi

\begin{tabular}{|c|c|c|c|c|c|c|}
\hline Varian & & $\mathrm{J}_{\mathrm{K}}$ & $\begin{array}{l}d \\
f\end{array}$ & $\begin{array}{l}\mathrm{M} \\
\mathrm{K}\end{array}$ & $F$ & Sig. \\
\hline 1 & Regression & 764.642 & 2 & 382.321 & \multirow[t]{3}{*}{25.796} & \multirow[t]{3}{*}{$.000^{\mathrm{a}}$} \\
\hline & Residual & 2815.959 & 190 & 14.821 & & \\
\hline & Total & 3580.601 & 192 & & & \\
\hline
\end{tabular}

Hasil analisis regresi ganda antara variabel konsep diri akademik dan kecerdasan emosi dengan prestasi akademik diperoleh nilai $F$ regresi sebesar 25.796 dengan taraf signifikansi $p=0,00(p<0,01)$ artinya konsep diri akademik dan kecerdasan emosi berkorelasi sangat signifikan dengan prestasi akademik siswa SMP.

Untuk mengetahui persamaan garis regresi linier berganda dilihat pada tabel berikut ini:

Tabel 6 : Output hasil uji regresi linier berganda

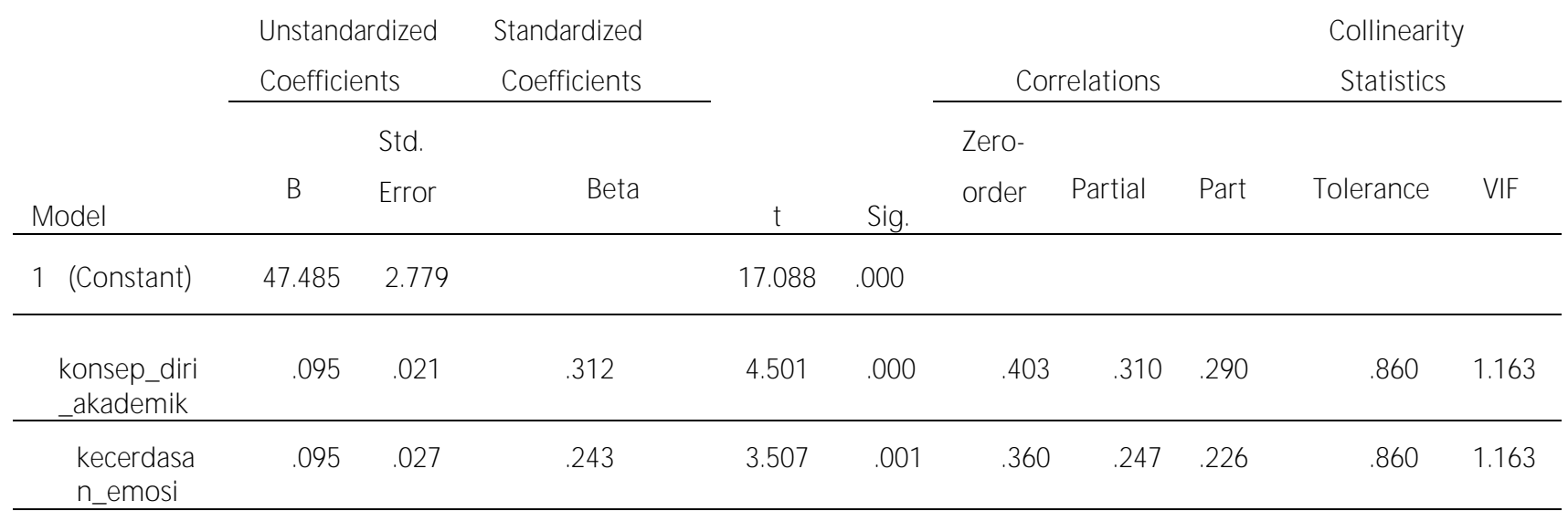

Dari tabel di atas di dapat persamaan regresi linier berganda sebagai berikut:

$$
\begin{aligned}
& Y^{\prime}=b_{0}+b_{1} X_{1}+b_{2} X_{2} \\
& Y^{\prime}=47,485+0,095 X_{1}+0,095 X_{2}
\end{aligned}
$$

Sedangkan besarnya hubungan dan besarnya sumbangan efektif variabel konsep diri akademik dan kecerdasan emosi secara bersama-sama dapat dilihat pada tabel berikut ini: 
Tabel 7 : Nilai Kontribusi Variabel Bebas Terhadap Variabel Terikat

\begin{tabular}{lccc} 
Variabel & $\mathrm{R}$ & $\mathrm{R}^{2}$ & Nilai Kontribusi \\
\hline $\begin{array}{l}\text { Konsep diri akademik*Kecerdasan } \\
\text { emosi }\end{array}$ & $.462^{\mathrm{a}}$ & .214 & $21,4 \%$ \\
\hline
\end{tabular}

Hasil uji regresi ganda antara variabel konsep diri akademik dan kecerdasan emosi dengan prestasi akademik menunjukkan bahwa besarnya koefisien korelasi $\mathrm{R}=0,462$ dan besarnya koefisien determinasi $\mathrm{R}^{2}=0,214$. Nilai koefisien korelasi $\mathrm{R}=0,462$ mengambarkan bahwa konsep diri akademik dan kecerdasan emosi secara bersama-sama mempunyai korelasi yang cukup kuat dengan prestasi akademik. Adapun besarnya determinan (sumbangan efektif) kedua variabel bebas dalam koefisien determinan sebesar $R^{2}=0,214$, artinya sumbangan efektif kedua variabel bebas secara bersamasama terhadap prestasi akademik adalah sebesar 0,214 x 100\% $=21,4 \%$. Sedangkan, $78,6 \%$ lainnya berasal dari variabel yang tidak diteliti dalam penelitian ini.

\section{Pembahasan}

Hasil analisis regresi menunjukkan bahwa secara bersama-sama variabel konsep diri akademik dan kecerdasan emosi memiliki hubungan yang positif dengan prestasi akademik dengan nilai $F=25,796$ pada taraf signifikansi sebesar $0,000(p<0,01)$ dengan nilai $R^{2}=0,214$. Hal ini membuktikan bahwa pernyataan hipotesis: "konsep diri akademik dan kecerdasan emosi mempunyai hubungan yang sangat postif dengan prestasi akademik siswa SMP" dapat diterima. Sumbangan efektif variabel konsep diri akademik dan kecerdasan emosi secara bersama-sama terhadap prestasi akademik sebesar $21,4 \%$ sedangkan $79,6 \%$ persen lagi dipengaruhi oleh variabel lain yang tidak diteliti dalam penelitian ini. Diterimanya hipotesis penelitian ini sejalan dengan hasil-hasil penelitian terdahulu yang menyatakan bahwa konsep diri akademik dan kecerdasan emosi merupakan dua variabel yang mempengaruhi prestasi akademik, semakin tinggi konsep diri akademik dan kecerdasan emosi maka akan semakin tinggi prestasi akademik siswa SMP.

Hasil penelitian ini sejalan dengan hasil penelitian yang dilakukan (Marsh et al., 2018); (Dent \& Koenka, 2016); (Gniewosz et al., 2015); (Chen et al., 2013);(Mclnerney et al., 2012) yang menemukan 
bahwa konsep diri akademik berkorelasi positif dengan prestasi akademik. Penelitian (Wouters et al., 2012) tentang pengaruh perubahan perkembangan konsep diri akademik pada siswa sekolah menengah menyebutkan bahwa konsep diri akademik secara positif berpengaruh terhadap perkembangan siswa dan juga peningkatan prestasi akademik. Hasil penelitian lain yang juga menemukan hasil yang sama adalah penelitian (Gonida \& Cortina, 2014) yang menyebutkan bahwa konsep diri akademik berhubungan secara langsung dengan prestasi akademik.

Siswa yang mempunyai konsep diri akademik yang tinggi akan memandang dirinya secara positif, percaya diri dan antusias dalam mencapai tujuan yang telah ditetapkan (Grygiel et al., 2017). siswa berprestasi tinggi dan mempunyai konsep diri akademik yang bagusakan memiliki rasa ingin tahu lebih banyak terhadap pelajaran di kelas dan aktif bertanya di kelas, membaca buku literatur dan sering berdiskusi dengan guru saat di luar kelas (Michael Jr., 2017)

Konsep diri akademik terbentuk dari pandangan individu yang bersangkutan tentang kemampuan dan keyakinan terhadap dirinya sendiri di bidang akademik. konsep diri akademik dapat diartikan sebagai pandangan, penilaian, perasaan, dan pengetahuan individu terhadap dirinya yang berhubungan dengan prestasi belajarnya atau kemampuannya di bidang akademik yang menyangkut dengan aspek kepercayaan diri, penerimaan diri dan penghargaan diri. Kekuatan positif yang terbentuk dari dalam diri individu, dalam hal ini konsep diri akademik akan membantu mendorong inidvidu dalam menetapkan tujuan ataupun goa/ yang akan dicapai seperti misalnya, siswa yang mempunyai konsep diri akademik yang positif akan menunjukkan sikap yang menunjukkan keterampilannya dalam mencapai keberhasilan atau menguasai materi dalam pelajaran sekolah dengan lebih baik dan percaya diri sehingga tercapai prestasi akademik yang diinginkan (Soroa et al., 2015). Sebaliknya, apabila siswa dengan konsep diri akademik negatif berarti ia memiliki persepsi, evaluasi atau penilaian negatif tentang kemampuan akademiknya yang akan membuat siswa tidak terdorong menjalankan aktivitas belajar dengan baik, artinya siswa pasif dalam aktivitas belajarnya, datang sekolah sering terlambat dan kurang rasa percaya diri terhadap kemampuan akademiknya.

Hasil penelitian ini juga menghasilkan pandangan bahwa kecerdasan emosi berkorelasi positif dengan prestasi akademik. Hasil penelitian ini mendukung temuan penelitian yang dilakukan oleh (Moye et al., 2013) yang menyatakan bahwa pada konteks kehidupan remaja dan dunia pekerjaan, kecerdasan emosi berperan penting dalam menangani masalah secara cepat dan tepat, menumbuhkan 
motivasi untuk berprestasi serta mampu merasakan apa yang diri dan orang lain rasakan. Temuan ini didukung pula oleh pendapat (Vlad, 2016) yang menyatakan bahwa dengan meningkatkan kecerdasan emosi dapat membantu seseorang untuk hidup menjadi lebih baik, selalu berpikir positif dan terus bersemangat untuk mencapai prestasi tertentu yang diharapkan. Hasil penelitian (Andonian, 2013) tentang kecerdasan emosi menunjukkan bahwa murid yang memiliki kecerdasan emosi tinggi ternyata jauh lebih sukses di sekolah, karena sangat toleran dengan perbedaan individu, dapat bekerjasama, memiliki kemampuan memecahkan masalah, berprestasi tinggi dan memiliki kompetensi sosial yang baik. Hasil penelitian (Garg et al., 2016) menunjukkan bahwa kecerdasan emosi berpengaruh secara signifikan terhadap prestasi akademik dan kompetensi sosial siswa untuk bertahan meneruskan studi di perguruan tinggi. Penelitian yang dilakukan oleh (Wigfield et al., 2015) tentang kecerdasan emosi menyebutkan bahwa remaja mampu menghadapi berbagai permasalahan atau stressor yang ada, dan mampu beradaptasi secara positif terhadap berbagai kondisi-kondisi yang menekan, sehingga remaja tetap dapat mempertahankan prestasi akademiknya.

Berdasarkan hasil penelitian ini dan juga penelitian-penelitian terdahulu yang sudah dilakukan mengenai kecerdasan emosi dan prestasi akademik maka dapat ditegaskan bahwa kecerdasan emosi berkorelasi secara postitif dengan prestasi akademik siswa, semakin tinggi kecerdasan emosi siswa, maka akan semakin tinggi prestasi akademiknya, sebaliknya semakin rendah kecerdasan emosi yang dimiliki siswa maka akan semakin rendah prestasi akademiknya.

\section{Kesimpulan}

Berdasarkan hasil analisis penelitian yang telah dikemukakan, dapat disimpulkan bahwa konsep diri akademik dan kecerdasan emosi secara bersama-sama berkorelasi secara positif dan mempunyai pengaruh yang signifikan terhadap prestasi akademik siswa. konsep diri akademik dan kecerdasan emosi berpengaruh terhadap perkembangan dan peningkatan prestasi akademik siswa. Individu yang memiliki konsep diri akademik dan kecerdasan emosi yang positif akan memandang dirinya secara positif, percaya diri dan antusias dalam mencapai prestasi akademik. individu juga mampu menghadapi dan menangani masalah secara cepat dan tepat dalam proses belajar mengajar. 


\section{Referensi}

Andonian, L. (2013). Emotional intelligence, self-efficacy, and occupational therapy students' fieldwork performance. Occupational Therapy in Health Care. https://doi.org/10.3109/07380577.2012.763199

Azwar, S. (2013). Kualitas Tes Potensi Akademik Versi 07a. Jurnal Penelitian Dan Evaluasi Pendidikan. https://doi.org/10.21831/pep.v12i2.1429

Bandura, A. (1989). Human Agency in Social Cognitive Theory. American Psychologist. https://doi.org/10.1037/0003-066X.44.9.1175

Billings, C. E. W., Downey, L. A., Lomas, J. E., Lloyd, J., \& Stough, C. (2014). Emotional Intelligence and scholastic achievement in pre-adolescent children. Personality and Individual Differences. https://doi.org/10.1016/j.paid.2014.01.017

Bornstein, M. H. (2018). The SAGE Encyclopedia of Lifespan Human Development. In The SAGE Encyclopedia of Lifespan Human Development. https://doi.org/10.4135/9781506307633

Burkhalter, A. D. (2014). Effects of Environmental and Instructional Factors on Student Motivation and Self-Directed. Journal of the American Academy of Special EducationAmerican.

Chen, S. K., Yeh, Y. C., Hwang, F. M., \& Lin, S. S. J. (2013). The relationship between academic self-concept and achievement: A multicohort-multioccasion study. Learning and Individual Differences. https://doi.org/10.1016/j.lindif.2012.07.021

Costa, A., \& Faria, L. (2015). The impact of emotional intelligence on academic achievement: A longitudinal study in Portuguese secondary school. Learning and Individual Differences. https://doi.org/10.1016/j.lindif.2014.11.011

Dent, A. L., \& Koenka, A. C. (2016). The Relation Between Self-Regulated Learning and Academic Achievement Across Childhood and Adolescence:A Meta-Analysis. Educational Psychology Review. https://doi.org/10.1007/s10648-015-9320-8

Erten, I. H., \& Burden, R. L. (2014). The relationship between academic self-concept, attributions, and L2 achievement. System. https://doi.org/10.1016/j.system.2014.01.006

Garg, R., Levin, E., \& Tremblay, L. (2016). Emotional intelligence: impact on post-secondary academic achievement. Social Psychology of Education. https://doi.org/10.1007/s11218-016-9338-x

Ghozali, I. (2016). Aplikasi Analisis Multivariate dengan Program IBM SPSS 23. (Edisi 8). Semarang: Badan Penerbit Universitas Diponegoro.

Gniewosz, B., Eccles, J. S., \& Noack, P. (2015). Early Adolescents' Development of Academic Self-Concept and Intrinsic Task Value: The Role of Contextual Feedback. Journal of Research on Adolescence. https://doi.org/10.1111/jora.12140

Goleman, D. (2014). Emotional Intelligence, Kecerdasan Emosional Mengapa El Lebih Penting daripada IQ. Jakata:PT Gramedia Pustaka Utama.

Gonida, E. N., \& Cortina, K. S. (2014). Parental involvement in homework: Relations with parent and student achievement-related motivational beliefs and achievement. British Journal of Educational Psychology. https://doi.org/10.1111/bjep.12039

Grygiel, P., Modzelewski, M., \& Pisarek, J . (2017). Academic self-concept and achievement in Polish primary schools: cross-lagged modelling and gender-specific effects. European Journal of Psychology of Education. https://doi.org/10.1007/s10212-016-0300-2 
Kashani, F. L., Azimi, A. L., \& Vaziri, S. (2012). Relationship between Emotional Intelligence and Educational Achievement. Procedia - Social and Behavioral Sciences. https://doi.org/10.1016/j.sbspro.2012.12.061

Khalaila, R. (2015). The relationship between academic self-concept, intrinsic motivation, test anxiety, and academic achievement among nursing students: Mediating and moderating effects. Nurse Education Today. https://doi.org/10.1016/j.nedt.2014.11.001

Marsh, H. W. (1990). The structure of academic self-concept: The Marsh/Shavelson model. Journal of Educational Psychology. https://doi.org/10.1037//0022-0663.82.4.623

Marsh, H. W., \& Martin, A. J. (2011). Academic self-concept and academic achievement: Relations and causal ordering. In British Journal of Educational Psychology. https://doi.org/10.1348/000709910X503501

Marsh, H. W., Pekrun, R., Murayama, K., Arens, A. K., Parker, P. D., Guo, J., \& Dicke, T. (2018). An integrated model of academic self-concept development: Academic self-concept, grades, test scores, and tracking over 6 years. Developmental Psychology. https://doi.org/10.1037/dev0000393

Mclnerney, D. M., Cheng, R. W. yi, Mok, M. M. C., \& Lam, A. K. H. (2012). Academic Self-Concept and Learning Strategies: Direction of Effect on Student Academic Achievement. Journal of Advanced Academics. https://doi.org/10.1177/1932202X12451020

Mega, C., Ronconi, L., \& De Beni, R. (2014). What makes a good student? How emotions, self-regulated learning, and motivation contribute to academic Achievement. Journal of Educational Psychology. https://doi.org/10.1037/a0033546

Mendoza, J. H., \& Hontiveros, E. P. (2017). Academic achievement, emotional intelligence and fluid intelligence as predictors of intrinsic career success of graduate students: basis for career development program. Asian Journal of Social Sciences \& Humanities.

Michael J r., R. D. (2017). Three Studies of Service-Learning as an Approach to Movement Integration in Elementary Classrooms. In ProQuest LLC.

Moye, J., Sabatino, C. P., \& Brendel, R. W. (2013). Evaluation of the capacity to appoint a healthcare proxy. American Journal of Geriatric Psychiatry. https://doi.org/10.1016/j.jagp.2012.09.001

Nurhasanah, K., \& Satrio Adi, R. (2018). APLIKASI KAMUS ISTILAH PSIKOLOGI BERBASIS ANDROID. KOPERTIP: Jurnal IImiah Manajemen Informatika Dan Komputer. https://doi.org/10.32485/kopertip.v2i1.35

Preckel, F., Gotz, T., \& Frenzel, A. (2010). Ability grouping of gifted students: Effects on academic selfconcept and boredom. British Journal of Educational Psychology. https://doi.org/10.1348/000709909X480716

Preckel, F., Niepel, C., Schneider, M., \& Brunner, M. (2013). Self-concept in adolescence: A longitudinal study on reciprocal effects of self-perceptions in academic and social domains. Journal of Adolescence. https://doi.org/10.1016/j.adolescence.2013.09.001

Schunk, D. H. (2012). Learning theories: An educational perspective. In Reading.

Skaalvik, E. M., \& Skaalvik, S. (2014). Teacher self-efficacy and perceived autonomy: Relations with teacher engagement, job satisfaction, and emotional exhaustion. Psychological Reports. https://doi.org/10.2466/14.02.PR0.114k14w0

Slameto, S. (2017). CRITICAL THINKING AND ITS AFFECTING FACTORS. Jurnal Penelitian Humaniora. https://doi.org/10.23917/humaniora.v18i2.5187 
Soroa, G., Balluerka, N., Hommel, B., \& Aritzeta, A. (2015). Assessing interactions between cognition, emotion, and motivation in creativity: The construction and validation of EDICOS. Thinking Skills and Creativity. https://doi.org/10.1016/j.tsc.2015.05.002

Suryabrata, S. (2015). Doc 11. In Psikologi Pendidikan.

Vlad, A. (2016). The study of the relationship between emotional inteligence and leadership style. Studiul Relatiei Dintre Inteligenta Emotionala Si Stilul de Leadership.

Wigfield, A., Eccles, J. S., Fredricks, J. A., Simpkins, S., Roeser, R. W., \& Schiefele, U. (2015). Development of Achievement Motivation and Engagement. In Handbook of Child Psychology and Developmental Science. https://doi.org/10.1002/9781118963418.childpsy316

Woolfolk, A. H. (2016). Educational psychology (13th ed.). In Educational psychology.

Wouters, S., De Fraine, B., Colpin, H., Van Damme, J., \& Verschueren, K. (2012). The effect of track changes on the development of academic self-concept in high school: A dynamic test of the big-fish-littlepond effect. Journal of Educational Psychology. https://doi.org/10.1037/a0027732

Za'im, M. (2016). Pendidikan Anak dalam Pengembangan Kecerdasan IQ, EQ dan SQ (Studi Kitab Tuhfat Al -Mawdud Bi Ahkam Al- Mawlud Karya Ibnu Al- Qayyim Al- Jauziyah). Muallimuna: Jurnal Madrasah Ibtidaiyah. 